\title{
The Essential Traits of Tourism Today: Values, Motivations and Trends*
}

\author{
Matteo Montebelli**, Massimiliano Vavassori ${ }^{* * *}$
}

\begin{abstract}
Tourism is driven by tourists and a traveller behaviour that has evolved over time, driven by changes in society. Trips have become shorter, there are a progressive disintermediation and cross-contamination, and increasingly selfdefining function as a time of personal realisation. Not just 'where' but also 'how' people travel is the key. The diverse motivations behind travel behaviour and holidays have gradually multiplied over the years and aspects traditionally considered of little or no relevance to tourism are gaining importance.
\end{abstract}

Keywords: Global Tourism; Tourist Experience; Travel Behaviour; Sharing Economy; Touring Club; Online Travel Agencies

\section{The Birth of Tourism}

People have always travelled and for the most diverse reasons, but not until the $19^{\text {th }}$ and $20^{\text {th }}$ centuries did travelling and staying in a place other than that of everyday life take on a specific meaning, that of getting away from ordinary life, seeking escape and the need for break a from the routine, especially for those assimilated into the industrial civilisation. Those were the days of stays at the seaside for health motives, when people strolled across the beach fully clothed and shaded from the sun, and of excursions in the salubrious air of the forest or mountain explorations up to the alpine glaciers. Italy stopped being a country visited only by foreigners and started to generate domestic tourism consisting in Italians travelling - albeit only those in small population segments. According to ISTAT (Italian National Institute of Statistics), $11.3 \%$ of Italians went away on at least one holiday in the year 1959; the figure almost doubled in 1965 (21\%) and tripled in 1975 (35.4\%) before levelling off from the mid-1980s on at approximately $50 \%$. The travel habit, at least for the Italians, has also played a major role in spreading knowledge of places outside national borders and in globalising the population - a very clear development of the last 50 years. In 1965, only $4.1 \%$ of travel by Italians was to a foreign country but this share steadily rose over the years, albeit at a fairly slow pace: to $5.4 \%$ in 1975 and $10.2 \%$ in 1985 ,

\footnotetext{
${ }^{*}$ Invited Article

** Head of Research \& Publication, Research Department Touring Club Italiano (matteo.montebelli@touringclub.it)

*** Director, Research Department Touring Club Italiano (massimiliano.vavassori@ touringclub.it)
} 
amounting today to approximately $25 \%$ of all journeys by Italians. These travellers were the focus of Touring Club Italiano (TCI) activities. Founded in Milan in 1894 to provide support to bicycle touring, within the space of just a few years it became a point of reference for all travellers, organising bicycle and car excursions across Italy, publishing first-class maps and guidebooks, and working to improve road networks and hospitality structures. These concrete initiatives stemmed, however, from high ideals - TCI aimed to 'help Italians get to know Italy', especially that unknown part excluded from traditional Grand Tour. In those decades between the two Wars, new types of travel and holidays were emerging - from Mediterranean cruises to spa holidays, popular since the mid-19 ${ }^{\text {th }}$ century thanks to the hydrotherapy health fad, school excursions, invented by TCI, and holiday camps that gave many children the opportunity of a seaside holiday. With the post-war reconstruction and the economic boom of the 1950s-60s, in particular, the Italians embraced mass tourism and holidays - predominantly at the seaside or in the mountains - became an integral part of a lifestyle that increasingly differentiated between leisure-time and work-time. The mountains were no longer just a place of exploration, with the emergence of several types of holiday there, from winter skiing to hiking; cultural trips to the nation's cities of art were also increasingly popular. The Italians started travelling abroad and the first TCI 'green guide' Svizzera (Switzerland) was published in 1961, the first in a successful series.

\section{How the Tourist Experience is Changing}

Tourism is driven by tourists and so, to understand it, we must decipher traveller behaviour and how it has evolved over time, driven by changes in society. Below, we highlight some of the trends behind today's tourist behaviour.

- Firstly, trips have become shorter. This has been a consolidated fact for some years. The days of month-long holidays (at the seaside) and a week's winter break in the mountains are no more. Tourism has - especially in the low season - been condensed into weekends or 3/4-night breaks. Of course, the recession of recent years plays a large part in explaining the gradual shortening of the holiday but is not all of the reason. This trend had already been seen in periods of economic stability. We can, perhaps, speak of a fragmentation of travel behaviour (more holidays a year satisfying different desires but for shorter times) which has recently been joined by a contingent requirement on the travellers' part to cut costs. This trend highlights the need to compress significant travel experiences into a short timeframe and, therefore, impacts strongly on the activities and services offered by the suppliers;

- Another feature of today's tourism is the progressive disintermediation. Several factors have, in recent years, facilitated a more autonomous approach to travel consumptions or, at least, it is intermediated differently from the past. This is caused by circumstances (e.g. the economic situation), structural reasons (the spread of ICT, giving access to less expensive and simpler forms of mobility etc.) and social motives (traveller maturity, the need for a personalised/unique travel experience etc.). The more traditional role of high-street travel agencies and tour operators has been supplemented by on-line agencies (OLTA), bed banks and lowcost airlines selling their product on the Internet. All this has suddenly opened travellers up to boundless opportunities to choose, access and personalise travel. In 
this sense, the traveller has become the protagonist, occupying spaces previously reserved for those working for the supply (the trade, in particular, but also national and local tourism agencies and even trade fairs). All this is fuelled by the countless pictures, videos and reviews available as an alternative on the Internet 24 hours a day/365 days a year and capable of inspiring dreams and desires that can then be made reality with a few clicks;

- The cross-contamination, also in the travel sector, produced by the spread of sharing and the sharing economy. Couchsurfing, i.e. the free exchange of hospitality, has been a concrete phenomenon for more than ten years now, since the principal player - couchsurfing.com - first appeared on the 'market' (2004). It currently has approximately 12 million registered users in 200 thousand cities and towns worldwide. One more recent but no less pervasive trend is that of Airbnb. Founded in 2008 in San Francisco, this website is based on a community that brings together people offering hospitality in exchange for payment and those in search of a bed. It has more than three million posts in more than 190 countries worldwide and a total of 150 million guests have used the website. In 2015, 150 thousand rooms were available in Italy (compared with an official infrastructure of 33,000 hotels and 124,000 other official forms of accommodation), managed by approximately 80,000 hosts. Also in 2015, 3.6 million travellers (Italian and non-) used Airbnb in Italy. It primarily targets - or ought to as this was its creators' intention - non-professionals who decide to rent out their house/apartment or rooms/beds to supplement their main income. Again, the demand is drawn to an immersive experience in the host's community or, at least, that is the promise. Nonetheless, it seems clear that contemporary travellers find this supply model more consistent and going against the traditional tourism dimension (inflexible and impersonal hotels, tourist menus, tour groups) from which they wish to detach in order to assert their individuality. The fact that this has become a widespread trend is also demonstrated by the response being given to the market by the destination of Copenhagen. Indeed, the strategic 2020 document on its DMO - Wonderful Copenhagen - begins by declaring "the end of tourism as we know it" and that "With the launch of our 2020 strategy, we set our course towards a future beyond tourism with something much more interesting and personal: a future of hosts and guests and the shared experience of localhood.";

- The trip is increasingly performing a self-defining function as a time of personal realisation. Contemporary travellers want personalised travel experiences, not mass and standardised ones but calibrated to their own needs and passions, and their own lifestyle. It is no coincidence that, according to TripBarometer 2014, the "unique experience" is the absolutely the top factor for travellers thinking about a holiday. Tourism has become an integral part of people's everyday lives and so is tending to gradually lose the exceptional feel (ritual of inversion) of past decades. The increasingly less clear separation between worktime and leisure-time has prompted greater 'personal' investment (in terms of values, needs, expectations) that spill over from everyday life into the practice of travelling;

- Not just 'where' but also 'how' people travel is key. Partly because, as citizens, we are ever more conscious of environmental values and our responsibilities towards the Planet. In their role as tourists, people are showing a growing focus on the importance of safeguarding and protecting the environment and local context in a broad sense. These trends do not only apply to travel experiences to distant and developing countries but also visits to the Old Continent and so-called 'traditional 
destinations', where the request for a tourism with less impact on the environment and local areas is emerging; one that offers an authentic and true snapshot of the local context. Companies - both in the hospitality and transport industries, and more recently in the food sector - are increasingly steering their communication towards the environmental sustainability of their supply (reduced energy/water consumption, careful waste disposal, use of organic produce etc.). It is no surprise, therefore, that approximately $40 \%$ of EU-28 citizens say their holiday choices are to some degree influenced by one or more factors reflecting a commitment to the environmental sustainability of public and private operators. From specific policies adopted by destinations, e.g. regarding local mobility, to direct initiatives by players in the tourist system such as environmental certification;

- Types of tourism. The diverse motivations behind travel behaviour and holidays have gradually multiplied over the years, further fragmenting the primitive distinctions (seaside, mountain and cultural) and generating a whole plethora of micro-motivations expressed in ever more crowded niche markets (food/wine, shopping, active, urban, well-being tourism etc.). At the same time, another growing phenomenon makes today's tourism even more complex, that of the progressive cross-contamination between different types of travel. For example, cultural tourism is increasingly bound to the local gastronomy but also to opportunities for shopping or the presence of events. The concrete result of this is the affirmation of so-called experiential tourism, as certified by a number of surveys such as the aforementioned TripBarometer. This relatively new expression places the focus on the individual and the experience which, over and above the (now many) motivations and the tyranny of the now tired concept of 'relaxation', constitute the true essence of contemporary travel;

- Aspects traditionally considered of little or no relevance to tourism are also gaining importance. Examples are craft traditions and local manufacture, now also key to the travel experience as too is gastronomy and, more generally speaking, the farming world. Several motivations underpin this new demand which expands the consolidated industries: we have new inbound markets - see China which is today our eighth inbound market and the importance of our manufacturing as a lever for Italy's appeal - but our everyday lifestyles and 'surroundings' are also changing. This is probably one of the factors that has had the most impact, for example, in the ongoing success of what can generically be described as 'rural' tourism. The more the metropolis becomes a source of apprehension (economic recession, unemployment, instability for the fear of terrorism etc.), the more the countryside seems reassuring. The more aggressive the present, the more (often erroneously) the past - of which the countryside is the archetype - appears gentle. The citydweller seems basically to be in search of simple and authentic emotions in a simpler world, which is therefore more attractive, or perceived to be so. The new cultural matrix of contemporary individuals has prompted them also to rediscover food, not merely for its 'instrumental' function but for what it represents, for its 'story'. It is no coincidence, in fact, that the quality (65\%) and geographic origin (34\%) of foodstuffs are increasingly prominent in the daily shopping choices of UE-28 citizens according to a European Commission Special Eurobarometer. This explains why the focus on the local food/wine offer and its narration has grown so much in the travel of recent decades;

- Finally, it is a fact that communication and technology are increasingly going hand-in-hand and that there is a close bond between them. Worldwide data confirm 
this as, although the coming years will bring an increased number of people using the Internet (from 3.2 billion today to 4 in 2018) and social networks (from 2 billion to 2.4), there will be an even higher rise in those using instant messaging (e.g. WhatsApp), from 2.5 billion to 3.6. Technology influences communication behaviour but also daily consumptions. Eurostat confirms that more than half the European population buys goods and services on-line and that, in type terms, tourism comes second. Moreover, at the "inspiration" stage of the trip alone, two thirds of people say they use the Internet and search engines, in particular, to look for information and ideas. Looking at the information sources that lead to the final travel decision, in UE-28 countries, the Internet plays a prominent role (63\%) with rating websites (e.g. TripAdvisor), in particular, being the ultimate 'places' for travel communications, those of the locations and social media are other 'forums' where people talk a great deal about travel, without forgetting how key the Internet has become for the more concrete phase of booking a holiday with 56\% of UE-28 citizens doing this online.

\section{Bibliography}

Bellini, N., \& Brondoni S. M. (2016). Ouverture de 'Global Tourism in Global Markets', Symphonya. Emerging Issues in Management (symphonya.unimib.it), 1, 1-6.

http://dx.doi.org/10.4468/2016.1.01ouveture

Brondoni, S.M. (2016). Global Tourism Management. Mass, Experience and Sensations Tourism. Symphonya. Emerging Issues in Management (symphonya.unimib.it), 1, 7-24.

http://dx.doi.org/10.4468/2016.1.02brondoni

Corti., A. (2016). Global Tourism. New Volatility, Old Statistics. Symphonya. Emerging Issues in Management (symphonya.unimib.it), 1, 25-30.

http://dx.doi.org/10.4468/2016.1.03corti

Dalonso, Y.S., Lourenço, J.M., Remoaldo, P.C., \& Netto A.P. (2014). Tourism experience, events and public policies. Annals of Tourism Research, 46, 163-184.

http://dx.doi.org/10.1016/j.annals.2014.03.003

European Commission (2012), Special Eurobarometer, Europeans' attitudes towards food security, food quality and the countryside.

European Commission (2016), Flash Eurobarometer, Preferences of Europeans towards tourism

Google (2014), Google Travel Study.

Massoletti, C. (2016). Tourists' Emotional Experiences in Global Markets. Symphonya. Emerging Issues in Management (symphonya.unimib.it), 2, 26-30.

http://dx.doi.org/10.4468/2016.2.04massoletti

Rizzi P., Graziano P. (2017). Turismo e sviluppo regionale in Ferlaino F., Jacobucci D., Tesauro C. (editori) Quali confini? Territori tra identità e integrazione internazionale. Franco Angeli, Milano

Skift Magazine (2016), Megatrends Defining Travel in 2016.

TripAdvisor (2014), TripBarometer.

UniCredit and Touring Club Italiano (2016), Rapporto sul turismo 2016.

Wonderful Copenhagen (2017), Strategy 2020. 